\title{
Recent Pocket Mouse Records for Saskatchewan
}

\author{
by Robert W. Nero, Regina
}

This note records the occurrence of the Olive-backed Pocket Mouse (Perognathus fasciatus) at 12 new localities in Saskatchewan (see Table). Previously records have been reported for 23 other localities (Nero, 1957, 1958 and 1959). Present records extend the range (as shown in Nero, 1958) to the east side of Last Mountain Lake and some 40 miles to the east of Regina. Efforts to locate pocket mice further east, mainly in the Broadview area where suitable habitat was found, have so far been unsuccessful. Some earlier records of pocket mice which have not been noted in the zoological literature are included.

Information on each of the records shown in the table follows:

1. While walking down a pasture trail on the Milo Boxrud farm six miles south and three miles east of Estevan about 3:00 a.m. on April 20, 1961, I saw a pocket mouse at my feet for a brief moment in the light of a flashlight. While I dislike introducing a sight record for this species, I feel that it was unmistakable under the circumstances. This locality is, of course, well within the known range for this species and only 20 miles or so from the North Portal record.

2. Ralph Carson, Gary Anweiler, and Ross Lein, while on a Sask. Museum of Nat. History field trip, collected four specimens along a sandy road close beside the South Saskat- chewan River at Saskatchewan Landing late at nigint in the car headlights. This was on June 16, 1961.

3. On. May 16, 1961, we collected a specimen after dark in the Big Muddy Valley bottoms, near the south side of the valley, about 11 miles south of Bengough.

4. Late at night and using the car headlights I caught a female and saw at least four others on May 23, 1961, along the edge of a road bordered by weeds in a sandy area on the west side (top of the valley) of Cottonwood Creek about $7 \frac{1}{2}$ miles WNW of Regina. I have since seen their signs in the same area on several occasions, e.g., fresh tracks on November 4, 1963.

5. During a biology class field-trip on September 26, 1961, a student brought me a carcass of a pocket mouse which he had found at the entrance of a badger burrow. This was west of Govan, near the shore of Last Mountain Lake. This is the first record for the east side of the lake.

6. I caught a female by hand in midmorning in some low brush along a fallow field. The mouse had apparently been started up by my dog. This was on October 21, 1961, about four miles NE of Ceylon.

7. A freshly killed Red-tailed Hawk which Ralph Carson and I found near Radville on October 28, 1961, was later found to contain a pocket mouse.

8. A male was collected at night on

Recent Pocket Mouse Records for Soskatchewan.

\begin{tabular}{|c|c|c|c|c|}
\hline Locality & Date & & Number & Collector \\
\hline 1. Estevan & April 20 & 1961 & 1 (sighted) & R. W. Nero \\
\hline 2. Sask. Landing & June 16 & 1961 & 4 & R. D. Carson et al \\
\hline $\begin{array}{l}\text { 3. Big Muddy Valley (near } \\
\text { Bengough) }\end{array}$ & May 16 & 1961 & 1 & R.W.N. \\
\hline $\begin{array}{l}\text { 4. Cottonwood Creek (near } \\
\text { Regina) }\end{array}$ & May 23 & 1961 & 1 & R.W.N. \\
\hline $\begin{array}{l}\text { 5. Last Mountain Lake (west } \\
\text { of Govan) }\end{array}$ & Sept. 26 & 1961 & 1 & R.W.N. \\
\hline 6. Ceylon & October 21 & 1961 & 1 & R.W.N. \\
\hline 7. Radville & October 28 & 1961 & 1 & R.W.N. \& R.D.C. \\
\hline 8. Strawberry Lakes & May 20 & 1962 & 1 & R.W.N. \& R.D.C. \\
\hline 9. North Portal & August 7 & 1962 & 1 & Ross Lein \\
\hline 10. Meyronne (6 mi. S.) & Oct. $13 \& 25$ & 1963 & 1,2 & R.W.N. et al \\
\hline 11. Beechy & June $5-6$ & 1964 & 2,5 & R.W.N. et al \\
\hline 12. Meyronne (6 $\mathrm{mi}$. SE) & October 9 & 1964 & 1 & R.W.N. \\
\hline
\end{tabular}


May 20, 1962, by me by hand on a trail road across a thin stand of open prairie on high sandy land between two of the Strawberry Lakes known locally as "Strawberry Lake" and "Raspberry Lake." This locality is south of Indian Head. This was a male in breeding condition (testes scrotal, weight 13.2 gms.) which was kept in captivity until it died on August 8, 1963; (skin discarded, measurements: total length-133., hind foot-17.5, tail -59., ear-7.). This was the only mouse seen in the area though we looked long and carefully for two nights and ran a trap-line. This area is quite sandy and provides a suitable habitat though surrounded by considerable aspen. This record extends the known range about 60 miles to the east (from the Cottonwood Creek locality).

9. Ross Lein caught one by hand on August 7,1962 , on a road at night in the car headlights about $51 / 2$ miles west of North Portal near the international border.

10. On October 13, 1963, we saw four and captured one at night in the sand dunes in the community pasture, six miles south of Meyronne. On October 25, 1963, in practically the same locality, we captured two at night.

11. We caught two late in the evening of June 5 , five in the late evening of June 6, and saw several others, in sandy prairie habitat close to the summer camp of the Society, about 10 miles southeast of Beechy. (See Nero, 1964, for details of other mammal species collected at the same time.)

12. On October 9,1964, while hunting about six miles southeast of Meyronne, my dog flushed a pocket mouse which was captured. This was at 11:00 a.m. in a sandy fallow field in which there were numerous signs of activity, e.g., burrows, tracks, of this species. There was no doubt that this mouse was clearly out of its burrow and active.

It is of interest to note that the pocket mouse in Saskatchewan seems to move about to some extent in the daytime; we now have two records of mice seen and captured in mid-morning (items 6 and 12), and presumably the mouse found as a food item in the Red-tailed Hawk (item 7) was captured during daylight hours. Anthony (1928:311) stated that this mouse was "strictly nocturnal" coming "out only after sundown." It may very well be that late in the fall the pocket mouse spends a maximum amount of time laying in stores of food and hence is also prone to work in daylight hours. Note that the three observations are for October 9, 21, and 28.

It is also clear that this species is active for at least eight months of the year in Saskatchewan. We now have dates as late as November 25 (1925, in Nero, 1957) and as early as April 1 (1960, beyond). This seems rather remarkable considering the nature of our climate, but these are perhaps more resourceful creatures than one would suspect. Pocket mouse remains were identified among the stomach contents of two of several dozen Great Horned Owls trapped by Keith Thue at the Provincial Game Farm, Beaver Creek (south of Saskatoon) as briefly reported by the late Dr. Robert Connell (1962). Parts of two rodents considered to be this species were found in a female owl received from the Game Farm, October 14, 1959, and one was found in a female owl received April 1, 1960 (personal correspondence, Robert Connell, 1962). Recently I wrote to ask Keith Thue about the April specimen as this date seemed rather early for that northern part of the range of the pocket mouse. In a letter dated January 5, 1965, Thue states: "There is no doubt in my mind at all that the owl referred to was supplied to Dr. Connell within a few days, a week at the most, after it was caught." This suggests that the mouse may have even been taken a few days earlier than the April 1 date. Note that the next earliest dates are April 20 (item 1), and April 23 (in Nero, 1957).

In a letter to Thue dated October 20,1959 , Dr. Connell gave this interesting report of his autopsy of one of the owls:

"247-Female [owl]. A few lice, all Strigiphilus oculatus. Stomach with remains of two small, mouse size sciuromorph rodents. I do not believe that these could be anything except Perognathus $s p$. (pocket mouse). One female flea was found in the stomach content. This was established to be a Meringis $s p$. In passing it through alcohols in preparation for cleaning, mounting and specific identification, Meringis was poured down the sink 
and lost in the five o'clock hurry to get away. With a stomach content containing Perognathus and Meringis this owl either came with it from near the United States border or else pocket mice range farther north than hitherto known." Dr. Connell, of course, had then not been aware of the report which included Beaver Creek as within their range (in Nero, 1958).

What were believed to be pocket mouse burrows were observed at Red Fox $[=$ Redfox $\mid$ Lake (in 1937) and at Swift Current Creek south of Gull Lake (in 1946) as reported by J. Dewey Soper (1961). Redfox Lake is in the Strawberry Lakes district.

Recently I came across some earlier records of pocket mice which have apparently been overlooked and which do not appear, so far as I know, in the zoological literature. In a report in the American Journal of Botany, Alexander Bakerspigel (1956) reports having trapped 260 mammals during a survey of Saskatchewan rodents for certain fungi. This was "from May to September, 1955." Ten pocket mice are included in his list of specimens (but these are not available). Species and localities are not related in this report, although his several trapping localities are shown. In an effort to determine the site at which the pocket mice were trapped I wrote to Dr. Bakerspigel for further information. In a letter dated January 14, 1965, he states: "As far as I can determine the general areas where the 10 pocket mice were trapped were a few miles south of Saskatoon and around Watrous." The nearest trap- ping site to Watrous is shown in his published report (1956) as being fairly close to the Saskatchewan River. This leads me to suggest that these speciments were probably trapped within the sandy region on the east side of the Saskatchewan River and some distance west of Watrous. In any event these sites are pretty well within the known range as recently established by some definite records.

I should also like to report that a male pocket mouse taken west of Nokomis on September 17, 1959, died in captivity on August 5, 1963.

I wish to thank the following persons who rendered assistance in searching for pocket mice: Gary Anweiler, Ralph D. Carson, Robert R. Taylor, Charles Thacker, and Alan Wade. Mr. and Mrs. Adam Deutscher deserve thanks for introducing me to the Strawberry Lakes region. A campout with Mr, and Mrs. Doug Wade, in which my family participated, provided an excuse for looking for pocket mice in that interesting locality.

\section{LITERATURE CITED}

Anthony, H. E. 1928. Field book of North American mammals. G. P. Putnam's Sons, N.Y. 625 pp., 48 plates.

Bakerspigel, A.' 1956. Endogone in Saskatchewan and Manitoba. Amer. Journ. Bot., 43:471-475

Connell, R. 1962. Stomach contents of Great Horned Owls. Blue Jay, 20:56-58.

Nero, R. W. 1957. The pocket mouse in Saskatchewan. Blue Jay, 15:172-173.

1958. Additional pocket mouse records. Blue Jav, 16:176-179.

1959. Some recent mammals records. Blue Jay, 17:169.

1964. Sagebrush Vole range extension and other records. Blue Jay, 22:119-120.

Soper, J. D. 1961. Field data on the mammals of southern Saskatchewan. Can. Field-Nat., 75:23-40.

\title{
Fabric from an Early Saskatchewan Trading Post
}

\author{
by Alice B. Kehoe, Regina
}

A unique discovery was made by the Saskatchewan Museum of Natural History archaeological expedition excavating a trading post built on the Saskatchewan River near Nipawin. The post, occupied 1768-1774, was operated by François le Blanc, an experienced French voyageur, and James Finlay, Sr., a Scottish immigrant who had become a merchant in Montreal. Their venture was a pioneering one, the only earlier trading post in Saskatchewan having been the short-lived outpost of Fort Paskoyac run by the Chevalier à la Corne. The phenomenal success of François' and Finlay's post encouraged other independent traders to penetrate up the Saskatchewan River, and forced the Hudson's Bay Company to establish its first inland post at Cumberland House.

The Saskatchewan Museum excav- 